\author{
Anna Jaśkiewicz \\ Uniwersytet Łódzki \\ Wydział Nauk Geograficznych \\ Instytut Geografii Miast i Turyzmu \\ anna.jaskiewicz92@gmail.com
}

\title{
POSTRZEGANIE SZLAKU ARCHITEKTURY PRZEMYSŁOWEJ ŁODZI PRZEZ MIESZKAŃCÓW MIASTA - PRZYKŁAD PARTYCYPACJI SPOŁECZNEJ W BADANIACH NAD TURYSTYKA
}

\begin{abstract}
Abstrakt: Łódź jako miasto postindustrialne posiada duży potencjał dla turystyki poprzemysłowej. Próbą jego wykorzystania było utworzenie Szlaku Architektury Przemysłowej Łodzi, łączącego obiekty związane z przemysłową przeszłością miasta. W opinii autorki, by szlak mógł pełnić funkcję atrakcji turystycznej pierwszymi osobami świadomymi jego wartości powinni być sami mieszkańcy. Przeprowadzone badania ankietowe potwierdziły niezwykle istotną rolę partycypacji społecznej w kreowaniu wizerunku miasta, stwarzającej podstawę do dalszych działań związanych z udoskonalaniem i promocją szlaku. Artykuł nie wyczerpuje tematu partycypacji społecznej w procesie rozwoju szlaku, ale może posłużyć jako wkład w dyskusję na temat roli mieszkańców w procesie kształtowania atrakcyjności turystycznej miasta. Partycypacja społeczna jest bowiem niezwykle istotnym elementem badań nad turystyką i stanowi wstęp do ich efektywnego wykorzystania w praktyce.
\end{abstract}

Słowa kluczowe: Szlak Architektury Przemysłowej Łodzi, Łódź, badania społeczne, partycypacja społeczna, turystyka przemysłowa, turystyka poprzemysłowa, turystyka industrialna, turystyka postindustrialna, rewitalizacja.

\section{WSTĘP}

Efektem wielkokapitalistycznego rozwoju przemysłu włókienniczego w XIX i na początku XX w. w Łodzi są liczne tereny postindustrialne, które stanowią ogromne dziedzictwo Łodzi. W ostatnich latach coraz więcej obszarów i obiektów pełniących w przeszłości funkcje przemysłowe jest rewitalizowanych i przystosowywanych do pełnienia funkcji turystycznych. Jest to spowodowane rosnącym zainteresowaniem turystyka przemysłową, co wynika m.in. z chęci poznawania własnego kraju i miasta. Można zatem przypuszczać, że obszary przemysłowe są znaczącym walorem turystycznym Łodzi.

Mieszkańcy miasta stanowią grupę, która ma stały kontakt z tkanką miejską. Niezwykle ważna jest zatem partycypacja społeczna, którą określa się jako aktywny udział mieszkańców w przygotowywaniu planów i podejmowaniu decyzji dotyczących ich bezpośredniego środowiska. W procesie tym ważną rolę odgrywają konsultacje społeczne, które mogą odbywać się bezpośrednio, np. w czasie spotkań, warsztatów, lub pośred- nio, np. poprzez badania ankietowe, referenda, fora dyskusyjne. Badania te umożliwiają mieszkańcom wpływ na decyzje dotyczące lokalnej wspólnoty, a także budują zaufanie do władz (HAUSNER, red. 1999). Temat zaangażowania mieszkańców w sprawy publiczne był często podejmowany w literaturze (m.in.: CZAPIŃSKI 2009, FRYKOWSKI 2005, PUTNAM 1995, SZAFRANEK 2008, SZAFRAŃSKA 2010), zatem partycypacja społeczna jest istotnym elementem badań nad turystyką i stanowi podstawę ich efektywnego rozwoju w praktyce.

W opinii autorki łodzianie są świadomi potencjału kulturowego miasta, jakim jest dziedzictwo przemysłowe. Być może jest to założenie przewrotne, ale jeżeli mieszkańcy miasta nie będą pozytywnie postrzegać kulturowego dziedzictwa swojego najbliższego otoczenia, nie wykreuje się atrakcji turystycznej docenianej przez szersze spektrum odbiorców. To właśnie mieszkańcy, w dobie kiedy opinie społeczne są coraz ważniejszym czynnikiem w procesie zarządzania miastem, mają możliwość wpływania na kształtowanie ota- 
czającej ich przestrzeni. Dowodem na to sa realizowane projekty $\mathrm{w}$ ramach budżetów obywatelskich. Dlatego też autorka za uzasadnione uważa przeprowadzenie badań ankietowych wśród mieszkańców miasta, mających na celu poznanie ich opinii na temat Szlaku Architektury Przemysłowej i perspektyw jego rozwoju. Przeprowadzone badania sondażowe mogłyby posłużyć podmiotom odpowiedzialnym za budowanie wizerunku miasta do stworzenia koncepcji promowania Łodzi w kontekście jej dziedzictwa przemysłowego.

Badania ankietowe prowadzono na forach internetowych na portalu społecznościowym Facebook, których członkami byli mieszkańcy poszczególnych dzielnic i osiedli w Łodzi, od początku listopada 2015 r. do końca stycznia 2016 r. Umożliwiło to dotarcie do dużej liczby osób w stosunkowo krótkim czasie. Wypełnionych zostało 300 kwestionariuszy. Respondentów wybrano metodą doboru kwotowego, gdzie za kluczową zmienną przyjęto dzielnicę zamieszkania, co umożliwiło odtworzenie struktury ogółu mieszkańców Łodzi. Zgodnie $\mathrm{z}$ tą zasadą $\mathrm{w}$ badaniu wzięły udział 84 osoby z Bałut, 72 z Górnej, 57 z Polesia, 57 z Widzewa i 30 ze Śródmieścia. Respondenci wybrani zostali za pomocą doboru okolicznościowego, nazywanego również doborem dostępnościowym (BABBIE 2005, FRANKFORT-NACHMIAS, NACHMIAS 2001). Założeniem autorki było prześledzenie opinii na temat szlaku w zależności od zajmowanego przez respondentów miejsca w przestrzeni geograficznej. Postawiono hipotezę, że mieszkańcy dzielnic, w których znajdują się obiekty poprzemysłowe, $z$ racji codziennego obcowania $z$ nimi będą bardziej doceniać ich wartość. Druga teza zakładała, że to właśnie mieszkańcy dzielnic, w których obiektów takich jest niewiele, będą szczególnie doceniać ich potencjał. Autorka zdawała sobie sprawę, że przeprowadzone badania nie są reprezentatywne i na ich podstawie nie można mówić o całej populacji mieszkańców Łodzi. Uważała jednak, że w kontekście kreowania nowej atrakcji turystycznej badania o charakterze sondażowym są uzasadnione i mogą stanowić wstępny etap do dalszej pracy nad budowaniem koncepcji wykorzystania istniejącego dziedzictwa.

\section{TURYSTYKA PRZEMYSŁOWA JAKO JEDEN Z RODZAJÓW TURYSTYKI KULTUROWEJ}

Dynamiczne zmiany zachodzące we współczesnej turystyce - spowodowane zwiększającą się świadomością społeczną potrzeb ochrony dziedzictwa zarówno kulturowego, jak i przyrodniczego, wynikającą z wzrostu poziomu wykształcenia obywateli Europy Zachod- niej - wpływają na zmianę motywów wyjazdów turystycznych. Opierając się na współczesnych tendencjach w zachowaniach turystycznych wyodrębniono nową formę turystyki poznawczej, będącą częścią turystyki kulturowej - turystykę przemysłową $(\mathrm{OCH}-$ MAŃSKI 2014). W związku z brakiem terminologicznego sprecyzowania wymiennie stosuje się również pojęcia: „turystyka industrialna”, ,turystyka poprzemysłowa", "turystyka w obiektach poprzemysłowych" oraz "turystyka dziedzictwa przemysłowego" (DEREK 2010); w literaturze przedmiotu istnieje wiele definicji tych terminów.

H. Handszuh określa turystykę dziedzictwa przemysłowego jako: „produkt oparty na wykorzystaniu odziedziczonych po poprzednich pokoleniach, a także współcześnie powstających miejsc, budynków, układów przestrzennych, urządzeń, narzędzi, przedmiotów, technologii i umiejętności mających zastosowanie w procesach produkcyjnych oraz związanych z nimi stylów życia i tradycji, sztuki i jej wytworów, które dają świadectwo rozwoju przemysłu i techniki, zarówno w przeszłości, jak i obecnie" (HANDSZUH 2005, s. 30-31).

Zgodnie z definicją A. Mikos v. Rohrscheidta turystyka kulturowa obiektów przemysłowych to: „podróże turystyczne, ukierunkowane głównie na zwiedzanie historycznych lub czynnych obiektów związanych $\mathrm{z}$ wydobyciem surowców, produkcją masową i techniką oraz krajobrazów przemysłowych. Pod warunkiem, że aspektem wiodącym tych podróży lub głównym motywem ich podjęcia jest zapoznanie się z historią zakładów, obiektów i urządzeń lub historycznym rozwojem procesów technologicznych oraz produktów. Istotny w tym rodzaju turystyki jest również aspekt przeżycia osobistego, spotkania z przemysłem, produkcją i techniką w miejscach autentycznych, związanych $\mathrm{z}$ ich historią, a także aktualną działalnością" (MIKOS V. ROHRSCHEIDT (2008, s. 121).

Podobnie turystykę dziedzictwa przemysłowego zdefiniował A. STASIAK (2009) uznając, że pod pojęciem tym należy rozumieć podróże, których głównym, a często $\mathrm{i}$ jedynym celem jest poznawanie dziedzictwa przemysłowego.

Zgodnie z definicją M. Derek turystyka przemysłowa jest „formą ruchu turystycznego, którego celem jest zwiedzanie obszarów, gdzie w przeszłości rozwijał się przemysł, a także obiektów i urządzeń związanych $\mathrm{z}$ rozwojem techniki i przemysłu, stanowiących dziedzictwo przemysłowe danego obszaru, jak również zwiedzanie współcześnie funkcjonujących przedsiębiorstw" (DEREK 2010, s. 188).

Precyzyjnego podziału rodzajów turystyki związanej z przemysłem dokonał M. KRONENBERG (2007), wyróżniając:

- turystykę przemysłową, która „obejmuje aktywność turystyczną na terenach działających 
zakładów przemysłowych związaną z poznaniem obecnych procesów produkcyjnych";

- turystykę na terenach poprzemysłowych, która „obejmuje aktywność turystyczną na terenach, gdzie dawna funkcja produkcyjna została zakończona, ale zachowane zostały z przeszłości ślady tej funkcji, np. budynki fabryczne";

- turystykę dziedzictwa przemysłowego, która „obejmuje aktywność turystyczną na terenach, gdzie dziedzictwo stanowi główną atrakcję i jego poznanie jest głównym motywem wizyty turysty".

$\mathrm{Z}$ powodu niedokładności $\mathrm{w}$ stosowaniu terminologii $\mathrm{w}$ tym zakresie $\mathrm{w}$ niniejszym artykule zdecydowano się stosować te pojęcia wymiennie.

\section{NARODZINY TURYSTYKI INDUSTRIALNEJ}

Pomysł na turystyczne i rekreacyjne wykorzystanie terenów i obiektów poprzemysłowych jest stosunkowo nowy. Pojawił się w latach 70. XX w. w Europie Zachodniej. Jego przyczyną była postępująca deindustrializacja, która spowodowała konieczność zastanowienia się nad tym, co zrobić z pozamykanymi fabrykami i jak zagospodarować zajmowane przez nie przestrzenie (JĘDRYSIAK 2011).

Zainteresowanie zabytkami techniki pojawiło się początkowo w krajach mających bogate tradycje w rozwoju przemysłu, takich jak: Wielka Brytania, Francja, Niemcy czy Szwecja. To właśnie w tych państwach zainicjowano nawiązywanie międzynarodowych kontaktów w dziedzinie ochrony zabytków przemysłu i techniki (JASIUK 2008).

Państwem, w którym zrodziła się turystyka dziedzictwa przemysłowego była Wielka Brytania, gdzie rozpoczęła się rewolucja przemysłowa. Problem z wykorzystywaniem obiektów poprzemysłowych nasilił się szczególnie w latach 50. i 60. XX w. Skutkowało to wzrostem popularności archeologii przemysłowej, której pionierzy zainteresowali wówczas społeczeństwo zabytkami techniki i przekonali do uznania ich za cenne dziedzictwo kulturowe (JĘDRYSIAK 2011). Dodatkowo był to również czas refleksji na temat niekorzystnego wpływu wielu zakładów na środowisko i możliwości przechodzenia na nowocześniejsze technologie. Spowodowało to likwidację wielu fabryk wykorzystujących tradycyjne metody produkcji (ORŁOWSKI 2008). Zamiast niszczyć pozostawione obiekty, zainwestowano $\mathrm{w}$ ich rewitalizację. Takim inicjatywom sprzyjała polityka państwa, które finansowo wspierało działania rewitalizacyjne, a także promocyjne, poprzez propagowanie dotychczasowych osiąg- nięć. Takie podejście szybko przeniosło się m.in. do Stanów Zjednoczonych i Niemiec (JĘDRYSIAK 2011).

Wraz z przekształcaniem się społeczeństw przemysłowych w społeczeństwa nowoczesne dawna praca produkcyjna stała się przedmiotem zainteresowania turysty. Zaczęto organizować tematyczne wycieczki z przewodnikiem po fabrykach, muzeach nauki i techniki. Docenienie wartości artystycznych i kulturowych takich obiektów stało się impulsem do powstania turystyki kulturowej dziedzictwa przemysłowego (JĘDRYSIAK 2011).

Jednym z pierwszych tego typu działań była rewitalizacja belgijskiej kopalni Blegny-Mines w latach 80 . XX w. Na jej terenie zbudowano park tematyczny oraz centrum sportowo-rekreacyjne $z$ hotelem. Innym pionierskim przykładem jest Zagłębie Ruhry w Niemczech, gdzie powstała sieć miejsc wypoczynkowych, liczne tereny rekreacyjne, parki naukowe oraz usługowe, a także centra technologiczne i inkubatory przedsiębiorczości. Otwarcie obiektów spowodowało dynamiczny wzrost liczby przykładów turystycznego wykorzystania obiektów poprzemysłowych (KRONENBERG 2012). Do innych przykładów należą m.in. kopalnia węgla kamiennego "Caphouse" w Yorkshire, dzielnica Castlefield w Manchesterze, doki św. Katarzyny w Londynie, kopalnia i koksownia "Zollverein" w Essen, kopalnia "Sachsen” w Hamm, łuskarnia ryżu "Lassie" i fabryka mydła „De Adelaar" w Holandii (JĘDRYSIAK 2011).

Wymienione przykłady świadczą o dostrzeganiu przez państwa europejskie znaczącej wartości obszarów poprzemysłowych i możliwości ich ponownego wykorzystania do celów edukacyjnych, rekreacyjnych i turystycznych. Zainteresowanie dawną kulturą, coraz bardziej zyskujące na popularności, w połączeniu z dużym potencjałem świadczą o pomyślnych perspektywach rozwoju turystyki postindustrialnej również na obszarze Polski i Łodzi (JĘDRYSIAK 2011).

\section{SZLAK ARCHITEKTURY PRZEMYSŁOWEJ ŁODZI}

Usystematyzowanie obiektów i połączenie ich w pewien spójny produkt umożliwia szlak turystyczny. Z. KRUCZEK (2007) za szlak turystyczny uznał wytyczoną na potrzeby zwiedzających trasę, która nie zawsze musi być oznakowana. Prowadzi do najbardziej atrakcyjnych miejsc lub obiektów z jednoczesnym zachowaniem przepisów dotyczących bezpieczeństwa i ochrony walorów. W ostatnich latach w Polsce zaczęto traktować szlaki turystyczne jako rodzaj produktu turystycznego. J. KACZMAREK, A. STASIAK i B. WŁODARCZYK (2010, s. 142) wyodrębnili definicję określenia 
„produkt turystyczny-szlak”, zgodnie z którą jest to „szczególny przypadek produktu turystycznego-miejsca (o charakterze liniowym, pasmowym, strefowym). Składa się z wielu miejsc lub obiektów związanych z pewną nadrzędną ideą, połączonych ze sobą wytyczoną, zwykle oznakowaną trasą (pieszą, wodną, samochodową itd.) oraz $\mathrm{z}$ różnej infrastruktury turystycznej zlokalizowanej wzdłuż szlaku". Wśród szlaków turystycznych wyróżnia się grupę szlaków tury- styczno-kulturowych, których ideą jest skupienie ich przebiegu wokół tematu z zakresu szeroko rozumianej kultury. W literaturze często zamiennie stosowane są terminy: "szlak kulturowy" oraz „szlak tematyczny". Wynika to z faktu, że wszystkie funkcjonujące szlaki kulturowe cechuje określona, węższa lub szersza, tematyka. Istnieje również możliwość tworzenia systemów penetracji turystycznej o przebiegu linearnym, o charakterze kulturowym, ale niepowiązanych

Tab. 1. Obiekty znajdujące się na Szlaku Architektury Przemysłowej Łodzi

\begin{tabular}{|c|c|c|c|c|c|}
\hline \multirow{2}{*}{ Lp. } & \multirow{2}{*}{ Nazwa obiektu } & \multirow{2}{*}{ Adres } & \multicolumn{2}{|r|}{ Funkcja } & \multirow{2}{*}{$\begin{array}{l}\text { Rewita- } \\
\text { lizacja }^{a}\end{array}$} \\
\hline & & & pierwotna & obecna & \\
\hline 1 & Biała Fabryka Ludwika Geyera & ul. Piotrkowska 282 & Fabryka & Muzeum, skansen, restauracja & + \\
\hline 2 & $\begin{array}{l}\text { Fabryka Fryderyka Wilhelma } \\
\text { Schweikerta }\end{array}$ & ul. Wólczańska 215 & Fabryka & Politechnika Łódzka & + \\
\hline 3 & $\begin{array}{l}\text { Magazyny fabryczne } \\
\text { Scheiblerów }\end{array}$ & ul. Tymienieckiego 3/5 & Magazyny fabryczne & $\begin{array}{c}\text { Siedziby organizacji i przed- } \\
\text { siębiorstw związanych } \\
\text { z kulturą } \\
\end{array}$ & + \\
\hline 4 & $\begin{array}{l}\text { Elektrownia fabryczna } \\
\text { Scheiblerów }\end{array}$ & ul. Tymienieckiego 5 & Elektrownia & $\begin{array}{c}\text { Siedziby organizacji i przed- } \\
\text { siębiorstw związanych } \\
\text { z kulturą }\end{array}$ & + \\
\hline 5 & Bielnik Tytusa Kopischa & ul. Tymienieckiego 5 & $\begin{array}{l}\text { Budynek mieszkalno- } \\
\text {-przemysłowy }\end{array}$ & Urząd Miasta Łodzi & + \\
\hline 6 & Fabryka Markusa Silbersteina & $\begin{array}{l}\text { ul. Piotrkowska } \\
242 / 250\end{array}$ & Fabryka & Obiekty handlowe & + \\
\hline 7 & Fabryka Zygmunta Richtera & ul. Stefanowskiego 17 & Fabryka & Obiekty handlowe i usługowe & - \\
\hline 8 & Nowa Tkalnia Karola Scheiblera & ul. Kilińskiego 187 & Fabryka & brak & - \\
\hline 9 & Szpital fabryczny Scheiblerów & ul. Milionowa 14 & Szpital & Szpital & + \\
\hline 10 & Przędzalnia Karola W. Scheiblera & ul. Tymienieckiego 25 & Fabryka & Obiekty mieszkalne & + \\
\hline 11 & Remiza strażacka Scheiblerów & ul. Tymienieckiego 30 & Remiza strażacka & Obiekty biurowe & + \\
\hline 12 & Domy robotnicze Scheiblerów & osiedle Księży Młyn & Obiekty mieszkalne & Obiekty mieszkalne & $+/-$ \\
\hline 13 & Szkoła fabryczna Scheiblerów & ul. Księży Młyn 13/15 & Szkoła & $\begin{array}{l}\text { Siedziba Akademickiego Cent- } \\
\text { rum Designu (trwają prace) }\end{array}$ & + \\
\hline 14 & Sklep fabryczny Scheiblerów & ul. Księży Młyn 14 & Sklep & $\begin{array}{l}\text { Siedziba wydawnictwa } \\
\text { „Księży Młyn”, restauracja }\end{array}$ & + \\
\hline 15 & Beczki Grohmanna & ul. Targowa 46 & Brama do fabryki & brak & + \\
\hline 16 & $\begin{array}{l}\text { "Centrala" zespół fabryczny } \\
\text { Scheiblera }\end{array}$ & pl. Zwycięstwa 2 & Fabryka & Obiekty usługowe & - \\
\hline 17 & Fabryka Winklera Gaertnera & ul. Sienkiewicza 82/84 & Fabryka & Centrum biznesowe & + \\
\hline 18 & Fabryka Józefa Balle & ul. Sienkiewicza 72 & Fabryka & Siedziby mediów & + \\
\hline 19 & $\begin{array}{l}\text { Fabryka Towarzystwa Akcyjne- } \\
\text { go Łódzkiej Manufaktury Nici }\end{array}$ & ul. Niciarniana 2 & Fabryka & Fabryka & - \\
\hline 20 & $\begin{array}{l}\text { Dom robotników Juliusza } \\
\text { Heinzla }\end{array}$ & ul. Tuwima 23/25 & Obiekty mieszkalne & Obiekty mieszkalne & - \\
\hline 21 & Elektrownia EC1 & ul. Targowa $1 / 3$ & Elektrownia & $\begin{array}{l}\text { Centrum kulturalno- } \\
\text {-artystyczne }\end{array}$ & + \\
\hline 22 & Fabryka Fryderyka Göldnera & ul. Rewolucji 1905 r. 52 & Fabryka & $\begin{array}{l}\text { Akademia Humanistyczno- } \\
\text {-Ekonomiczna }\end{array}$ & + \\
\hline 23 & Imperium Izraela Poznańskiego & ul. Ogrodowa 17 & $\begin{array}{l}\text { Kompleks } \\
\text { przemysłowy }\end{array}$ & $\begin{array}{l}\text { Centrum handlowo- } \\
\text { kulturalno-rozrywkowe }\end{array}$ & + \\
\hline 24 & $\begin{array}{l}\text { Domy robotnicze Izraela } \\
\text { Poznańskiego }\end{array}$ & ul. Ogrodowa 24, 26, 28 & Obiekty mieszkalne & Obiekty mieszkalne & $+/-$ \\
\hline 25 & Fabryka Ernsta Wevera & ul. Kopernika 3 & Fabryka & Obiekty handlowe i usługowe & + \\
\hline 26 & Fabryka Juliusza Kindermanna & ul. Łąkowa 23/25 & Fabryka & Hotel & + \\
\hline 27 & Fabryka Adolfa Daube & ul. Wólczańska 128/134 & Fabryka & Centrum biznesowe & + \\
\hline
\end{tabular}

${ }^{a}$ W tabeli uwzględniono stan przygotowania obiektów do zwiedzania: „,+" to obiekty zrewitalizowane, ",-" obiekty niezrewitalizowane ,"/-" obiekty zrewitalizowane częściowo.

Źródło: opracowanie własne. 


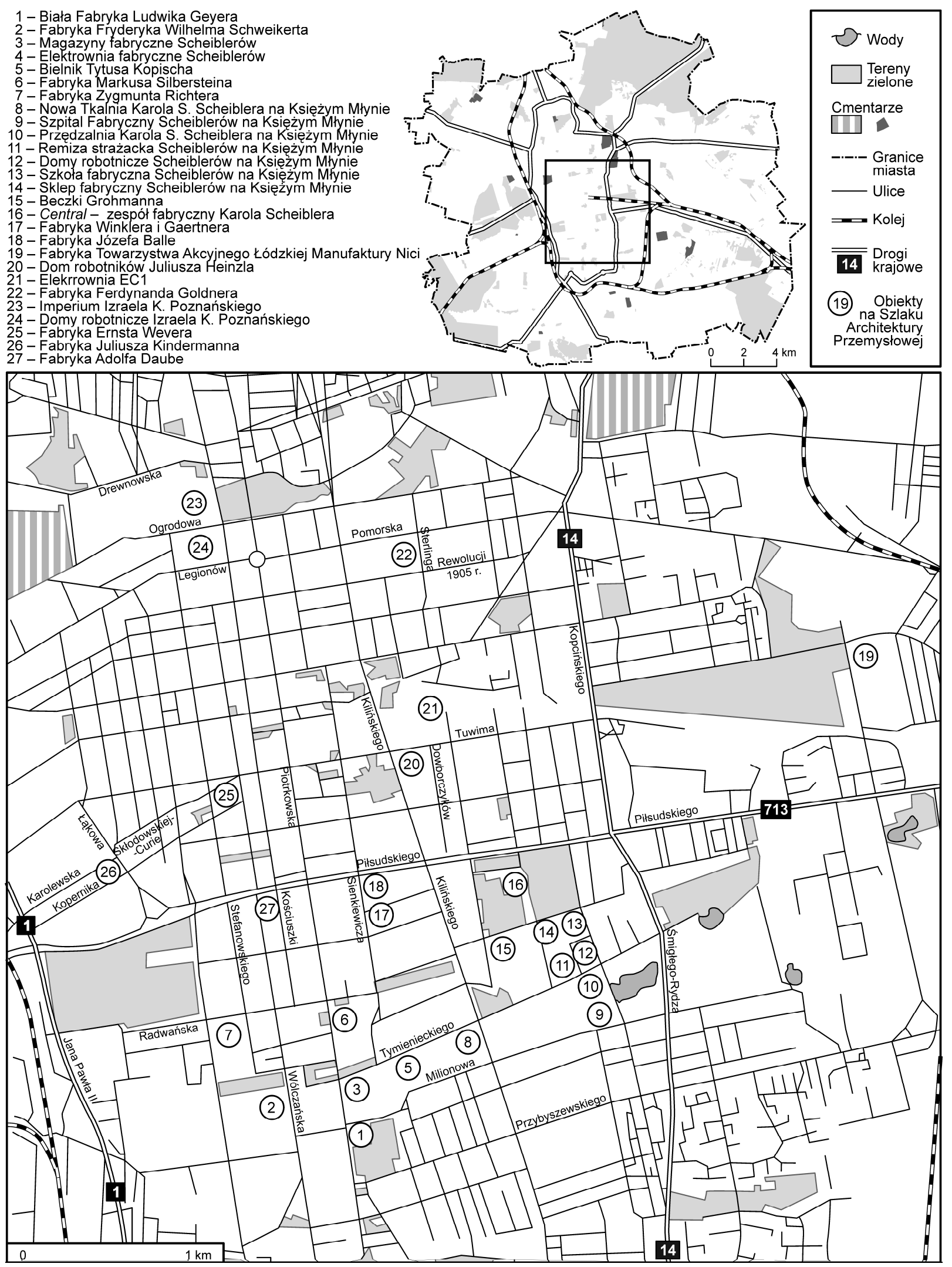

Rys. 1. Rozmieszczenie obiektów na Szlaku Architektury Przemysłowej Łodzi Źródło: opracowanie własne na podstawie badań 
jednym spójnym tematem. Na ich określenie stosuje się wówczas termin: multitematyczne szlaki kulturowe lub multitematyczne szlaki dziedzictwa (MIKOS V. ROHRSCHEIDT 2010). Na potrzeby niniejszego artykułu zdecydowano się traktować pojęcia: „szlak kulturowy" i "szlak tematyczny" jako tożsame. J. TOMCZAK (2013, s. 49-51) przyjmuje następującą definicję szlaku tematycznego: "Szlak tematyczny to zintegrowany i zarządzany linearny system penetracji rekreacyjnej, składający się $\mathrm{z}$ obiektów reprezentujących dany temat $w$ przestrzeni, łączaccej je trasy oraz elementów oferty towarzyszącej, mogących mieć związek $\mathrm{z}$ tematem w różnych ujęciach. Szlak powinien umożliwić poznanie i zrozumienie istoty danego tematu, a także ułatwić uprawianie turystyki poprzez odpowiednie zagospodarowanie szlaku, umożliwiające odwiedzającemu łatwe poruszanie się po nim i zdobywanie informacji o szlaku i jego elementach składowych" (TOMCZAK 2013, s. 49-51).

Szlak tematyczny tworzy więc integralną całość, koncentrując zainteresowanie zwiedzającego na konkretnym temacie, przez pryzmat którego postrzega on otaczającą przestrzeń. Najistotniejsza jest zatem treść szlaku, w mniejszym stopniu natomiast oznaczenie i elementy zagospodarowania.

Za uzasadnione uważa się zatem uznanie Szlaku Architektury Przemysłowej za przykład szlaku tematycznego. Jednocześnie szlak tematyczny łączący elementy stanowiące przedmiot zainteresowania osób uprawiających turystykę przemysłową należy uznać za przemysłowy szlak tematyczny.

Szlak Architektury Przemysłowej Łodzi tworzy 27 obiektów, z których większość została zrewitalizowana i przystosowana do pełnienia nowych funkcji (tab. 1). Spacer szlakiem pozwala poznać historię miasta, którego potęgą był w przeszłości przemysł włókienniczy.

Szlak Architektury Przemysłowej zlokalizowany jest $\mathrm{w}$ centrum Łodzi. Szlak nie ma wytyczonej trasy ani zagospodarowania, a tworzą go jedynie punktowo rozmieszczone obiekty (rys. 1). Są one zlokalizowane we wszystkich dzielnicach Łodzi (rys. 2).

Ponad połowa obiektów (14) zlokalizowana jest w dzielnicy Widzew. Znaczną ich część (6) stanowią zabudowania Księżego Młyna, takie jak: szpital, przędzalnia, remiza strażacka, domy robotnicze, szkoła, sklep. Do pozostałych zabudowań należą: magazyny fabryczne Scheiblerów, elektrownia fabryczna Scheiblerów, Bielnik Tytusa Kopischa, Nowa Tkalnia Karola W. Scheiblera, Beczki Grohmanna, „Centrala” - zespół fabryczny Scheiblera, Fabryka Towarzystwa Akcyjnego Łódzkiej Manufaktury Nici oraz Elektrownia EC1.

Wśród sześciu obiektów zlokalizowanych w Śródmieściu znajduje się pięć fabryk: Markusa Silbersteina, Winklera i Gaertnera, Józefa Balle, Ferdynanda Göld- nera, Adolfa Daube oraz Dom Robotników Juliusza Heinzla.

Kolejną dzielnicą jest Polesie, gdzie znajdują się cztery fabryki: Fryderyka Wilhelma Schweikerta, Zygmunta Richtera, Ernsta Wevera oraz Juliusza Kindermanna.

Dzielnica Bałuty posiada dwa zespoły obiektów związane z Izraelem Poznańskim - „imperium” (dzisiejsza Manufaktura) oraz domy robotnicze.

Jedynym obiektem mieszczącym się w dzielnicy Górna jest Biała Fabryka Ludwika Geyera.

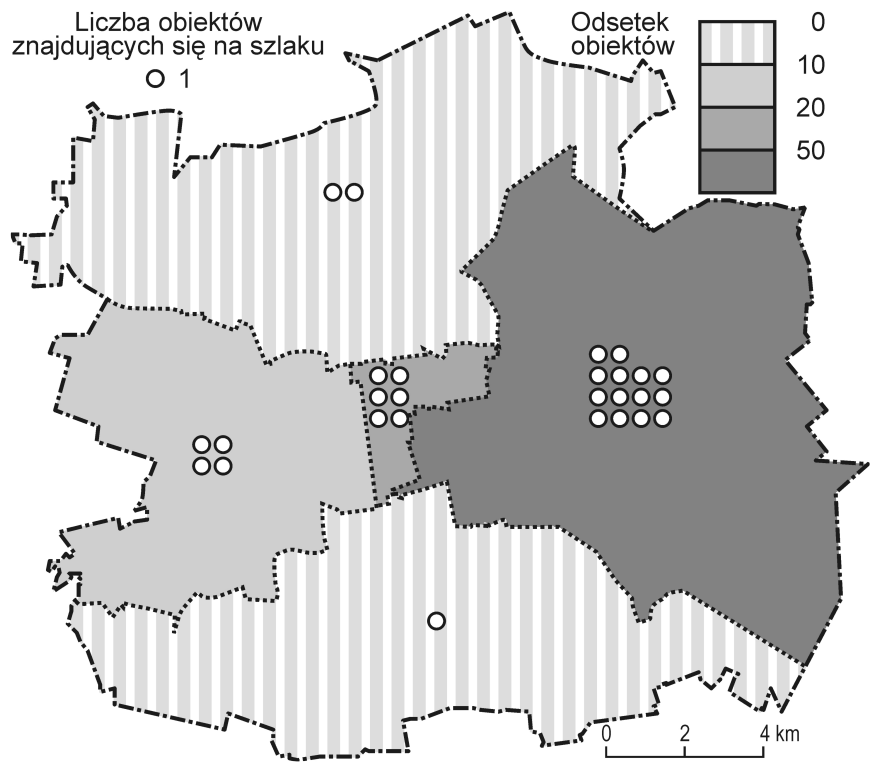

Rys. 2. Rozmieszczenie obiektów Szlaku Architektury Przemysłowej w dzielnicach Łodzi

Źródło: opracowanie własne na podstawie badań

Promocją Szlaku Architektury Przemysłowej Łodzi zajmuje się Urząd Miasta Łodzi. Podstawowym materiałem promocyjnym jest broszura dotyczaca szla$\mathrm{ku}$, dostępna w punktach informacji turystycznej oraz niektórych łódzkich obiektach noclegowych. W broszurze krótko scharakteryzowano wszystkie obiekty znajdujące się na szlaku, wraz z zaznaczniem ich lokalizacji na mapie, oraz przybliżono historię największych łódzkich rodów fabrykanckich. Broszura zamieszczona jest także na stronie internetowej Urzędu Miasta, w zakładce poświęconej turystyce. Szlak został w czerwcu 2010 r. objęty również projektem „Odkoduj Łódź”. Zleceniodawcą projektu był Urząd Miasta Łodzi, a wykonawcą firma Mobile MS. Był to pierwszy w Polsce tego typu projekt, a jego ideą było dostarczenie użytkownikom dodatkowych informacji na temat obiektów za pomocą fotokodów. System używany jest również do prowadzenia gier miejskich. 


\section{POSTRZEGANIE SZLAKU ARCHITEKTURY PRZEMYSŁOWEJ ŁODZI PRZEZ MIESZKAŃCÓW MIASTA}

Wśród ankietowanych łodzian kobiety stanowiły 68\%, mężczyźni natomiast 32\%. Wyróżniono siedem grup wiekowych. Największą (41\%) stanowiły osoby w wieku 20-29 lat, pozostałe reprezentowały przedziały: 30-39 lat (17\%), do 19 lat (14\%), 40-49 lat (12\%) i 50-59 lat (10\%). Najmniej liczną grupę stanowili respondenci w wieku 60-69 lat (5\%). Nikt z ankietowanych nie przekroczył 70. roku życia.

Najwięcej osób zadeklarowało wykształcenie wyższe $(35 \%)$, wielu badanych miało wykształcenie średnie $(24 \%)$. Pozostali ankietowani legitymowali się licencjackim $(16 \%)$, policealnym $(9 \%)$ oraz podstawowym (8\%). Najmniej respondentów wykazało wykształcenie gimnazjalne (5\%) i zawodowe (3\%).

Ponad połowa badanych to osoby pracujące (53\%). Drugą największą grupą byli uczniowie i studenci (36\%). Niewielki odsetek ankietowanych stanowili emeryci $(5 \%)$, bezrobotni $(4 \%)$ i renciści $(1 \%)$. Na strukturę wykształcenia i statusu zawodowego bezpośredni wpływ miała struktura wieku.

O Szlaku Architektury Przemysłowej Łodzi wcześniej słyszało 54\% respondentów. Pozostali (45\%) potwierdzili, że o nim nie słyszeli. Prawdopodobnie niektórzy ankietowani odpowiedzieli na pytanie twierdząco, nie do końca mając świadomość funkcjonowania szlaku, a jedynie utożsamiając miasto $\mathrm{z}$ obiektami postindustrialnymi. Potwierdza to fakt, że na pytanie: "Skąd dowiedzieli się o szlaku?" - 10 respondentów, którzy wcześniej odpowiedzieli, że słyszeli o szlaku, nie wskazało żadnej odpowiedzi (rys. 3).

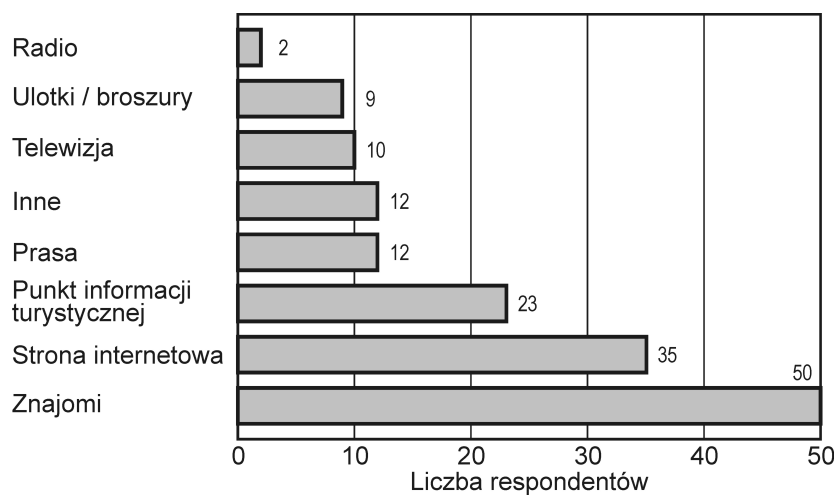

Rys. 3. Źródło informacji o Szlaku Architektury Przemysłowej Łodzi

Źródło rys. 3-9: opracowanie własne na podstawie badań ankietowych

Najpopularniejszym źródłem wiedzy o szlaku byli znajomi (33\%), co potwierdza duże znaczenie tzw. marketingu szeptanego $\mathrm{w}$ rozpowszechnianiu infor- macji. Wielu respondentów wskazywało również na wykorzystanie strony internetowej (23\%; rys. 4 ) oraz punktu informacji turystycznej (15\%). Źródłem wie$\mathrm{dzy}$ na ten temat była również prasa $(8 \%)$, telewizja $(7 \%)$, ulotki i broszury $(6 \%)$ oraz radio $(1 \%)$. Kilkunastu respondentów (8\%) podało także inne źródła pozyskania informacji, takie jak: szkoła, mąż, uczelnia.

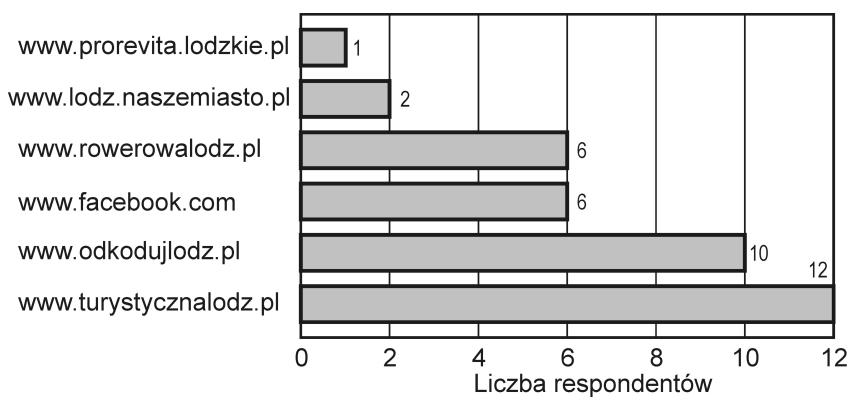

Rys. 4. Strony internetowe jako źródło informacji o Szlaku Architektury Przemysłowej Łodzi

Najczęściej wskazywaną stroną internetową była strona Urzędu Miasta Łodzi poświęcona turystyce: www.turystycznalodz.pl (12 wskazań), a także www. odkodujlodz.pl (10), portal społecznościowy Facebook (6) i www.rowerowalodz.pl (6). Ankietowani powoływali się również na strony: www.lodz.naszemiasto.pl (2) i www.prorevita.lodzkie.pl (1).

Zaledwie $61 \%$ respondentów, którzy wcześniej odpowiedzieli, że słyszeli o Szlaku Architektury Przemysłowej Łodzi, potrafiło wymienić jakiś obiekt znajdujący się na szlaku. Potwierdza to przypuszczenie, że wiedza wielu łodzian na temat szlaku była bardzo powierzchowna (rys. 5).

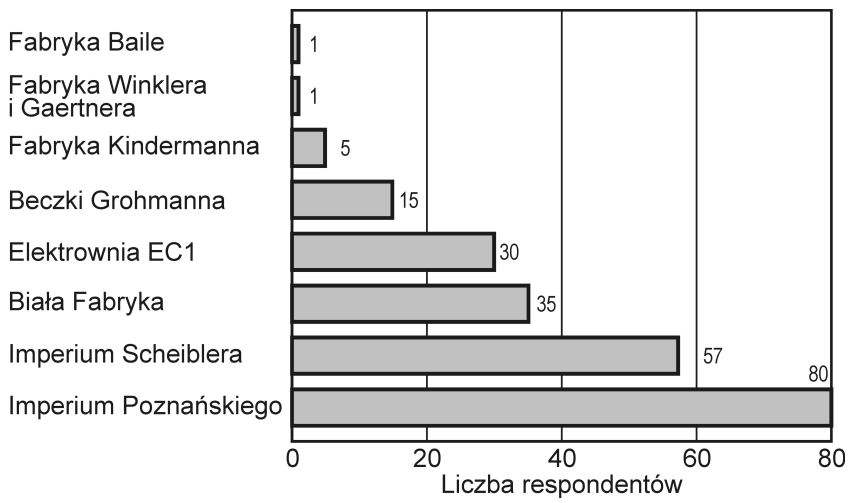

Rys. 5. Obiekty znajdujące się na Szlaku Architektury Przemysłowej Łodzi wskazane przez respondentów

Najczęściej wskazywanym przez respondentów obiektem znajdującym się na wskazanym szlaku było „imperium” Poznańskiego (80 wskazań), a na drugim miejscu znalazło się „imperium” Scheiblera (57). W odpowiedzi dotyczącej obiektów na szlaku znala- 
zły się także wskazania pojedynczych elementów kompleksu przemysłowego, takie jak: Elektrownia Scheiblera (2), famuły (3), remiza strażacka (3). Często podawano także Białą Fabrykę (35), Elektrownię EC1 (30), Beczki Grohmanna (15), a sporadycznie wymieniano: Fabrykę Kindermanna (5), Fabrykę Winklera i Gaertnera (1) oraz Fabrykę Józefa Balle (1). Tylko połowa ankietowanych, którzy wykazali, że słyszeli o Szlaku Architektury Przemysłowej Łodzi, uzasadniło, dlaczego uważa wskazane obiekty za atrakcyjne (rys. 6).

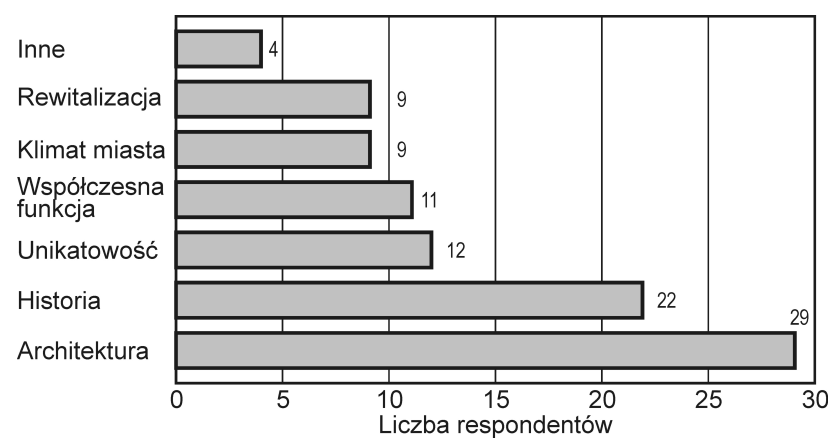

Rys. 6. Uzasadnienie atrakcyjności wskazanych przez badanych obiektów Szlaku Architektury Przemysłowej Łodzi

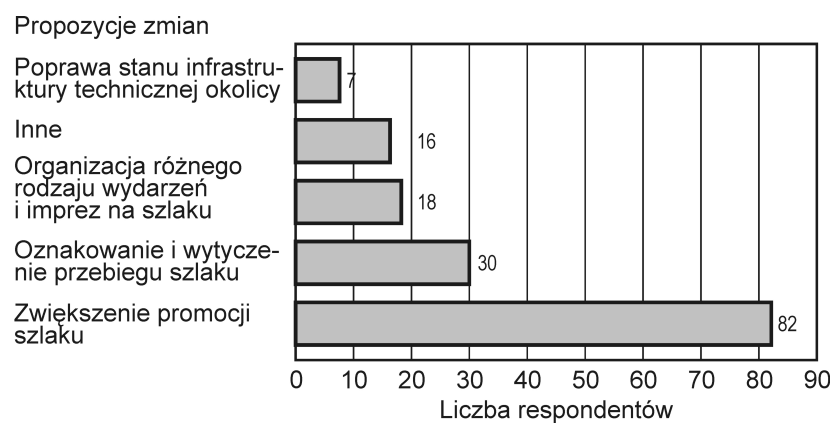

Rys. 7. Propozycje zmian mające na celu zwiększenie atrakcyjności Szlaku Architektury Przemysłowej Łodzi w opinii respondentów

Respondenci jako uzasadnienie atrakcyjności wskazanych obiektów podawali wartość architektoniczną (29) oraz historyczną (22). Dla wielu o atrakcyjności obiektów świadczyła ich unikatowość w skali miasta, kraju i Europy (12), współcześnie pełniona funkcja obiektów (11) oraz fakt, że tworzą niepowtarzalny klimat miasta i że są przykładami doskonałej rewitalizacji obiektów zabytkowych (9). Ankietowani opisali obiekty takimi przymiotnikami, jak: piękne (2), niepowtarzalne (1), ogromne (1). Wśród uzasadnień pojawiły się także oryginalne odpowiedzi, a wśród nich: "Gdy się na nie patrzy, można poczuć klimat tamtych czasów, kiedy Łódź była przemysłowym imperium", "Są wizytówką miasta w kraju i za granicą", "Mieszkałam tam blisko i oglądałam je latami, i wiem, że tworzą piękną historię miasta", "Stanowią dominanty w łódzkiej przestrzeni".
Wszyscy ankietowani mieli propozycję zmian mających na celu zwiększenie atrakcyjności Szlaku Architektury Przemysłowej Łodzi. Nikt nie wskazał odpowiedzi, aby nic nie zmieniać, co z jednej strony świadczy o tym, że szlak wymaga dopracowania i udoskonalenia, a z drugiej pokazuje pomysłowość mieszkańców i ich zainteresowanie potencjalnym produktem turystycznym (rys. 7).

Najwięcej badanych uważało, że aby zwiększyć atrakcyjność szlaku należy zintensyfikować jego promocję (54\%) oraz oznakować szlak i wytyczyć jego przebieg (20\%). Respondenci przyznali, że dobrym pomysłem na zwiększenie atrakcyjności szlaku byłaby organizacja różnego rodzaju wydarzeń i imprez (12\%). Za poprawą stanu infrastruktury technicznej w okolicy (np. utworzenie ławeczek, koszy na śmieci, ścieżek rowerowych) opowiedziało się 5\% ankietowanych. Były także własne pomysły na zwiększenie atrakcyjności wskazanego szlaku - poprzez zaznaczenie odpowiedzi „inne” (10\%). Najczęściej proponowano stworzenie aplikacji na telefon komórkowy z przewodnikiem po obiektach (5 wskazań), zorganizowanie corocznego wydarzenia związanego z łódzkimi fabrykami (np. Festiwal Łódzkich Fabryk czy Light Move Festival) (4), a także utworzenie szlaku rowerowego, którego trasa przebiegałaby w pobliżu obiektów (2). Respondenci zasugerowali także zadbanie o wygląd pobliskich ulic i budynków, umieszczenie tablic informacyjnych $\mathrm{z}$ mapą szlaku, a także stworzenie tematycznych pętli na szlaku.

Znaczna większość respondentów przyznała, że jeszcze nie zwiedzała szlaku, ale chciałaby (71\%). Dużo mniej osób odpowiedziało, że nie było na Szlaku Architektury Przemysłowej Łodzi i nie są zainteresowani jego zwiedzeniem (15\%), a także że już było i chciałoby zwiedzić go jeszcze raz (13\%). Zaledwie 1\% badanych przyznało, że byli na nim, ale nie chcieliby zwiedzać go ponownie. Chęć zwiedzenia szlaku, którą przejawiło $84 \%$ ankietowanych, świadczy o zainteresowaniu mieszkańców Łodzi obiektami postindustrialnymi i dostrzeganiu w nich atrakcyjności, a także przejawianiu pozytywnego stosunku do idei szlaku. Widoczna jest zależność pomiędzy wiekiem respondentów a stosunkiem do szlaku (rys. 8).

Ponad połowa badanych, którzy odpowiedzieli, że nigdy nie byli na omawianym szlaku i nie chcieliby go zwiedzić (56\%), to osoby młode - do 19 lat. Jest to dowód na najmniejsze zainteresowanie obiektami postindustrialnymi oraz samym szlakiem dzieci i młodzieży, co nie może budzić zdziwienia - ani tematyka, ani obiekty zwykle nie stanowią atrakcji dla tak młodych ludzi. Osoby w wieku 20-29 lat (50\%) i 40-49 lat (50\%) wykazały, że zwiedzały szlak, ale nie zamierzają powtórnie tego robić. Grupy zainteresowane szlakiem były najbardziej zróżnicowane ze względu na wiek, co dowodzi, że główną determinantą oceny szlaku są 
osobiste zainteresowania i upodobania respondentów. Ponad połowa osób (54\%), które chciałyby zwiedzić szlak przyznała, że w obcowaniu z obiektami poprzemysłowymi najbardziej są ciekawi ich historii. Respondenci wyrażali również zainteresowanie architekturą (33\%) oraz funkcją, jaką obiekt pełni współcześnie $(13 \%)$.

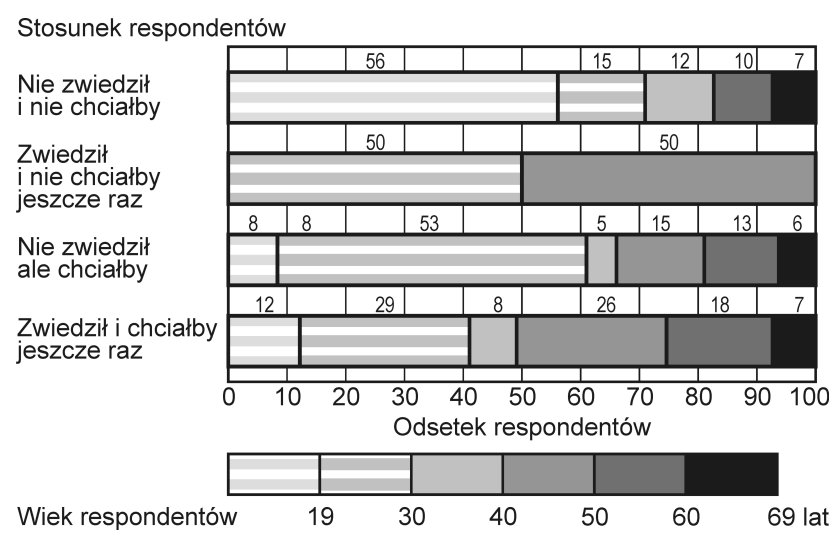

Rys. 8. Stosunek respondentów do zwiedzania Szlaku Architektury Przemysłowej Łodzi w zależności od wieku

Uwaga: Za zwiedzenie szlaku uznaje się odwiedzenie co najmniej trzech obiektów podczas jednej wyprawy

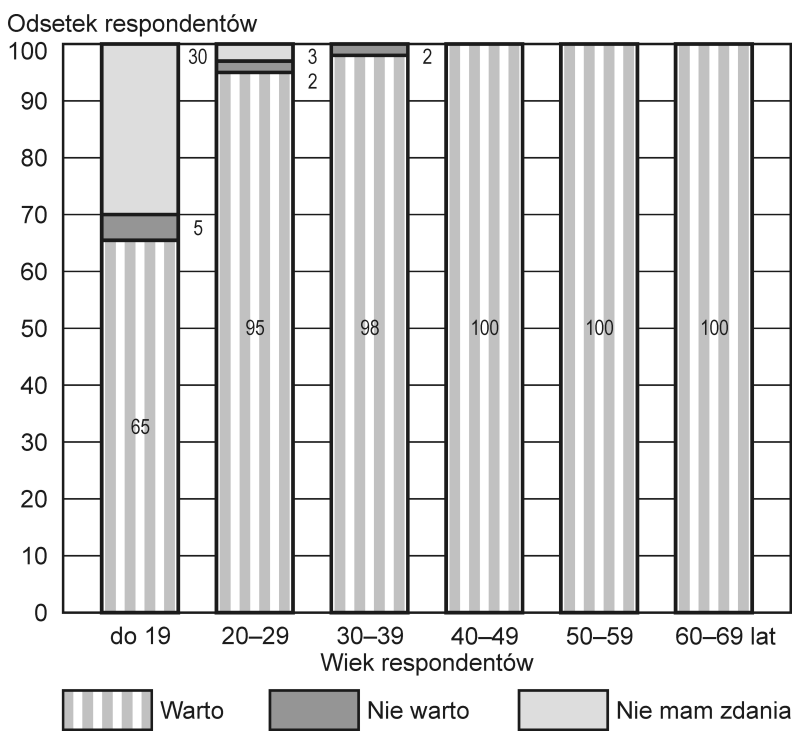

Rys. 9. Opinia respondentów na temat potrzeby rewitalizacji obiektów postindustrialnych

Największa grupa badanych przyznała, że chciałaby zwiedzić szlak indywidualnie (47\%) lub w zorganizowanej grupie z przewodnikiem (42\%). Stosunkowo niewiele osób chciałoby odwiedzić szlak wirtualnie (9\%). Ankietowani (2\%) mieli również własne pomysły na zobaczenie szlaku, takie jak: wycieczka rowerowa po szlaku (3 osoby) oraz zorganizowana wycieczka zabytkowym autobusem (2 osoby).
Zdecydowana większość respondentów (92\%) przyznała, że warto rewitalizować obiekty pełniące w przeszłości funkcje przemysłowe, a zaledwie $2 \%$ badanych wyraziło zdanie przeciwne. Pozostali (6\%) nie mieli zdania na ten temat. Znaczący wpływ na strukturę odpowiedzi miał wiek respondentów (rys. 9).

Ankietowani, którzy uznali, że nie warto rewitalizować obiektów poprzemysłowych, to ludzie młodzi, w wieku do 19 lat (5\%) i 20-29 lat (2\%). Wraz z wiekiem malała liczba odpowiedzi wskazujących na brak zdania w tej kwestii (do 19 lat - 30\%, 20-29 lat - 3\% i 30-39 lat - 2\%), jednocześnie rosła liczba respondentów wyrażających pozytywny stosunek do rewitalizacji (do 19 lat - 65\%, 20-29 lat - 94\%, 30-39 lat - 98\%, 40-69 lat - 100\%). Dowodzi to, że dostrzeganie zalet rewitalizacji wzrasta wraz $\mathrm{z}$ wiekiem, a sam proces doceniany jest głównie przez osoby dojrzałe.

Reasumując wyniki badań ankietowanych mieszkańców Łodzi, można stwierdzić, że ocena Szlaku Architektury Przemysłowej Łodzi w głównej mierze zależała od osobistych upodobań oraz subiektywnych odczuć respondentów. Na poziom zainteresowania szlakiem nie wpływa ani płeć respondenta, ani dzielnica jego zamieszkania, jak początkowo sądziła autorka. Znaczącą determinantą w postrzeganiu szlaku był jednak wiek respondentów. Najmniej przychylny stosunek do szlaku oraz procesu rewitalizacji wyrażały osoby młode (do 19 lat). Przypuszcza się, że jest to spowodowane niższym poziomem wiedzy tej grupy badanych, a także niewielkim doświadczeniem życiowym.

\section{PODSUMOWANIE}

Pełnienie funkcji przemysłowej przez blisko dwa stulecia spowodowało istnienie ogromnego dziedzictwa przemysłowego na obszarze Łodzi. Zespoły fabryczno-rezydencjonalne, powstałe $\mathrm{w}$ różnych stylach architektonicznych fabryki, budynki produkcyjne, pałace i wille, a nawet nekropolie fabrykantów stanowią kulturę materialną regionu (KACZMAREK, LISZEWSKI, WŁODARCZYK 2006). Początkowo obiekty dziedzictwa przemysłowego i technicznego nie były wyodrębniane w podręcznikach jako objęte ochroną, co świadczyło o ich niewielkim znaczeniu dla mieszkańców (KONOPKA 1994). S. LISZEWSKI (1992) potwierdzil, że mimo ogromnego i dobrze zachowanego potencjału obiekty przemysłowe nie budziły dużego zainteresowania wśród ludności zarówno Łodzi, jak i całego kraju. Wraz z rozwojem społeczno-gospodarczym Polski i umacnianiem się demokracji postrzeganie obszarów postindustrialnych uległo zasadniczej zmianie. Szansą na ich rozwój stała się rewitalizacja. E. SZAFRAŃSKA (2010, s. 64-65) jest zdania, że „zdecydowana więk- 
szość mieszkańców miasta niezależnie od ich miejsca zamieszkania dostrzega potrzebę rewitalizacji terenów/obiektów poprzemysłowych, wyraża zainteresowanie ich przyszłością i chce być informowana o planach działań lub/i konkretnych działaniach rewitalizacyjnych podejmowanych na terenach poprzemysłowych".

Szansą na restrukturyzację wielu obszarów postindustrialnych było wprowadzenie na nie funkcji turystycznej. Uzasadnienie działań i zmian na tych terenach spowodowane było nie tylko czynnikiem ekonomicznym, ale także zmieniającymi się motywacjami i upodobaniami turystów poszukujących nowych form turystyki. Symbolem tego jest przejście od turystyki 3S (ang. see, sand, sun) do turystyki 3E (ang. excitement, entertainment, education) i 4H (ang. heritage, handicraft, habitat, history) (KOWALCZYK 2008). Podobny problem został zaprezentowany $\mathrm{w}$ artykule zatytułowanym Przestrzeń czasu wolnego w obiektach poprzemystowych na warszawskiej Pradze. Pomyst na sukces? przez M. DEREK (2012), co potwierdza fakt, że istnienie w mieście obiektów postindustrialnych stwarza duże możliwości dla rozwijania w nim turystyki.

Zachowane dziedzictwo kulturowe odgrywa również ważną rolę $\mathrm{w}$ procesie edukacji, kształtując postawy społeczne. Odnosi się to przede wszystkim do młodego pokolenia, które rzadko dostrzega walory historyczne, kulturowe czy architektoniczne obiektów przemysłowych, co zostało potwierdzone w różnych badaniach (SZALPUK 2005).

Liczne obiekty poprzemysłowe w Łodzi stanowią ogromny potencjał dla rozwoju turystyki. Walorem w tej dziedzinie jest Szlak Architektury Przemysłowej Łodzi, który przy odpowiednim „oszlifowaniu” mógłby stać się istotną atrakcją turystyczną miasta. Niewątpliwym atutem szlaku jest jego na ogół pozytywna percepcja przez samych mieszkańców miasta, a więc osób, które jako pierwsze powinny być świadome jego wartości. Łodzianie na ogół kreatywnie podchodzą do rozwoju i promocji szlaku. Badania wykazały, że mieszkańcy mają także wiedzę merytoryczną o dziedzictwie kulturowym miasta, w którym żyją, co dowodzi, że mają podstawy do decydowania o jego losach w aspekcie turystycznego rozwoju.

Autorka założyła, że wpływ na postrzeganie obiektów przemysłowych ma zajmowane przez łodzian miejsce w miejskiej przestrzeni geograficznej. Doprowadziło to do wysnucia dwóch przeciwstawnych hipotez:

1. Mieszkańcy dzielnic, w których znajdują się obiekty poprzemysłowe, $\mathrm{z}$ racji codziennego obcowania $\mathrm{z}$ nimi bardziej doceniają ich wartość.

2. Mieszkańcy dzielnic, w których jest niewiele obiektów poprzemysłowych szczególnie doceniają ich potencjał.
Żadna $\mathrm{z}$ tez nie została potwierdzona. Determinantą $\mathrm{w}$ postrzeganiu szlaku okazał się natomiast wiek respondentów. Najmniej przychylnie i obojętnie o szlaku wypowiadały się osoby młode (do 19. roku życia). Uznano to za niepokojący wniosek w procesie analizowania roli partycypacji społecznej. Mimo że współpraca lokalnych władz z mieszkańcami oceniana jest na ogół pozytywnie i współcześnie jest coraz częściej stosowana, to niesie również ze sobą ryzyko podejmowania decyzji pochopnych i nieprzemyślanych. W konsultacjach społecznych moga przecież brać udział osoby niekompetentne do decydowania, czego przyczyną może być zarówno brak wiedzy merytorycznej, niedojrzałość emocjonalna, jak i po prostu odmienny światopogląd. Złe decyzje mogą być wówczas bardzo szkodliwe dla rozwoju miasta i skutkować nieodwracalnymi konsekwencjami. Niezwykle istotny jest zatem starannie przemyślany dobór decydentów, wśród których nie powinny znaleźć się osoby przypadkowe.

\section{BIBLIOGRAFIA}

BABBIE E., 2005, Badania społeczne w praktyce, Wyd. Naukowe PWN, Warszawa, 659 ss.

CZAPIŃSKI J., 2009, Diagnoza społeczna 2009. Warunki i jakość życia mieszkańców, Wyd. Vizja Press \& IT, Warszawa, 420 ss.

DEREK M., 2010, Turystyka przemystowa, [w:] A. Kowalczyk (red.), Turystyka zrównoważona, Wyd. Naukowe PWN, Warszawa, s. 188-208.

DEREK M., 2012, Przestrzeń czasu wolnego w obiektach poprzemystowych na warszawskiej Pradze, [w:] B. Włodarczyk (red.), Moda na sukces, "Warsztaty z Geografii Turyzmu”, t. 2, Wyd. Uniwersytetu Łódzkiego, Łódź, s. 49-66.

FRANKFORT-NACHMIAS CH., NACHMIAS D., 2001, Metody badawcze w naukach społecznych, Zysk i S-ka, Poznań, 615 ss.

FRYKOWSKI M., 2005, Zaufanie społeczne mieszkańców Łodzi, Wyd. Uniwersytetu Łódzkiego, Łódź, 226 ss.

HANDSZUH H., 2005, Tworzenie wzorca jakości dla turystyki dziedzictwa przemystowego, [w:] T. Burzyński, M. Łabaj (red.), Dziedzictwo przemystowe jako atrakcyjny produkt dla turystyki i rekreacji. Doświadczenia krajowe i zagraniczne. Materiaty z II konferencji międzynarodowej, Zabrze, 12-13.05.2005, Wyd. GWSH, Katowice, s. 29-39.

HAUSNER J. (red.), 1999, Komunikacja i partycypacja społeczna, Małopolska Szkoła Administracji Publicznej Akademii Ekonomicznej w Krakowie, Kraków, 198 ss.

JASIUK J., 2008, Dziedzictwo przemystowe. Doceniony element tradycji oraz społecznego i turystycznego wykorzystania w Polsce $i$ w Europie, [w:] W. Kaprowski, F. Midura, J.W. Sienkiewicz (red.), Dziedzictwo przemystowe Mazowsza i jego rola w turystyce, Zakład Wydawniczy DrukTur sp. z o.o., Warszawa, s. 13-19.

JĘDRYSIAK T., 2011, Turystyka kulturowa w obiektach poprzemystowych - zagadnienia ogólne, „Turystyka Kulturowa”, 6, Wyd. KulTour.pl, Poznań, s. 8-27.

KACZMAREK J., LISZEWSKI S., WŁODARCZYK B., 2006, Strategia rozwoju turystyki w Łodzi, Łódzkie Towarzystwo Naukowe, Łódź, 129 ss. 
KACZMAREK J., STASIAK A., WŁODARCZYK B., 2010, Produkt turystyczny, Wyd. Ekonomiczne SA, Warszawa, 446 ss.

KONOPKA M., 1994, Obiekty przemystowe też mogą być zabytkami. Istota ochrony dziedzictwa kultury technicznej, [w:] M. Smoktunowicz (red.), Rewitalizacja zabytków techniki. Nowe życie $w$ starych zakładach przemystowych. Materiaty $z$ konferencji, Ośrodek Dokumentacji Zabytków, Warszawa, s. 15-22.

KOWALCZYK A., 2008, Geografia turyzmu, Wyd. Naukowe PWN, Warszawa, 287 ss.

KRONENBERG M., 2007, Turystyka dziedzictwa przemystowego - próba sprecyzowania terminologii, [w:] T. Burzyński (red.), Dziedzictwo przemystowe jako strategia rozwoju innowacyjnej gospodarki. Materiaty z IV Międzynarodowej konferencji naukowo-praktycznej, Zabrze, 6-7.09.2007, Wyd. GWSH, Katowice, s. 33-41.

KRONENBERG M., 2012, Wptyw zasobów dziedzictwa przemystowego na atrakcyjność turystycznq miasta. Przykład Łodzi, Wyd. Uniwersytetu Łódzkiego, Łódź, 224 ss.

KRUCZEK Z., 2007, Geografia turystyczna, Proksenia, Kraków, 304 ss.

LISZEWSKI S., 1992, The industrial city as a tourist centre. The example of Łódź, „Turyzm”, 2, 1, s. 9-22.

MIKOS V. ROHRSCHEIDT A., 2008, Turystyka kulturowa. Fenomen, potencjat, perspektywy, Wyd. GWSH Milenium, Gniezno, s. $51-172$.

MiKOS V. ROHRSCHEIDT A., 2010, Regionalne szlaki tematyczne: idea, potencjat, organizacja, Wyd. Proksenia, Kraków, 408 ss.

OCHMAŃSKI A., 2014, Interpretacja dziedzictwa przemystowego dla potrzeb turystyki edukacyjnej na przykładzie Szlaku Zabytków
Techniki Województwa Śląskiego, [w:] K. Widawski, M. Duda-Seifert (red.), Turystyka przemystowa w kontekście rozwoju zrównoważonego, Instytut Geografii i Rozwoju Regionalnego Uniwersytetu Wrocławskiego, Wrocław, s. 119-137.

ORŁOWSKI B., 2008, Fenomen turystyki industrialnej, Akademia Humanistyczna im. Aleksandra Gieysztora, Pułtusk-Ciechanów, 60 ss.

PUTNAM R., 1995, Demokracja w dziataniu. Tradycje obywatelskie we wspótczesnych Wtoszech, Wyd. Znak, Kraków, 324 ss.

STASIAK A., 2009, Zabytki techniki i przemystu, [w:] A. Stasiak (red.), Geografia turystyki Polski. Przewodnik do ćwiczeń krajoznawczych, PWE, Warszawa, s. 89-107.

SZAFRANEK E., 2008, Kapitał ludzki i spoteczny w przestrzeni miasta. Przykład Łodzi, [w:] J. Słodczyk, E. Szafranek (red.), Mechanizmy $i$ uwarunkowania budowania konkurencyjności miast, Uniwersytet Opolski, Opole, s. 63-77.

SZAFRAŃSKA E., 2010, Rewitalizacja terenów poprzemystowych Łodzi w opinii mieszkańców miasta, [w:] T. Markowski, S. Kaczmarek, J. Olenderek (red.), Rewitalizacja terenów poprzemystowych $w$ Łodzi, KPZK PAN, Warszawa, s. 41-67.

SZALPUK G., 2005, Uwarunkowania $i$ szanse rozwoju turystyki industrialnej na terenie województwa lubuskiego, [w:] T. Burzyński, M. Łabaj (red.), Dziedzictwo przemystowe jako atrakcyjny produkt dla turystyki i rekreacji. Doświadczenia krajowe $i$ zagraniczne. Materiaty z II konferencji międzynarodowej, Zabrze, 1213.05.2005, Wyd. GWSH, Katowice, s. 239-247.

TOMCZAK J., 2013, Szlak kulinarny jako przykład szlaku tematycznego, „Prace i Studia Geograficzne”, 52, s. 47-62.

Artykuł wpłyną:

15 kwietnia $2017 \mathrm{r}$.

Zaakceptowano do druku:

14 czerwca $2017 \mathrm{r}$ 